\title{
Morphophysiogenetic characterization of wild poinsettia biotypes with low resistance to glyphosate
}

\author{
Dirceu Agostinetto(1), André da Rosa Ulguim(2), Leandro Vargas ${ }^{(3)}$, \\ Jessica Dias Gomes da Silva ${ }^{(1)}$ and Ana Claudia Langaro(1)
}

\begin{abstract}
(1)Universidade Federal de Pelotas, Faculdade de Agronomia Eliseu Maciel, Departamento de Fitossanidade, Caixa Postal 354, Campus Universitário, CEP 96160-000 Capão do Leão, RS, Brazil. E-mail: dirceu.agostinetto@pq.cnpq.br, jessicadiasgomes@hotmail.com, namelia.langaro@gmail.com (2)Universidade Federal de Santa Maria, Campus Universitário, CEP 97105-900 Santa Maria, RS, Brazil. E-mail: andre.ulguim@ufsm.br ${ }^{(3)}$ Embrapa Trigo, Rodovia BR-285, Km 294, s/n. ${ }^{\circ}$ CEP $99050-970$ Passo Fundo, RS, Brazil. E-mail: leandro.vargas@embrapa.br
\end{abstract}

\begin{abstract}
The objective of this work was to compare wild poinsettia (Euphorbia heterophylla) biotypes as to their morphological characteristics, as well as to determine their genetic similarity in the state of Rio Grande do Sul, Brazil, and to confront the light compensation point of susceptible biotypes and of biotypes with low-resistance level to glyphosate. Besides the morphology analysis, the study included the genetic characterization, by AFLP, of susceptible $\left(\mathrm{GR}_{50}=58.65 \mathrm{~g} \mathrm{ha}^{-1}\right.$ a.e. $)$ biotypes and of biotypes with low resistance $\left(\mathrm{GR}_{50}=310.36 \mathrm{~g}^{-1}\right.$ a.e. $)$ to glyphosate. The competitive ability of the biotypes was inferred according to their light compensation point. The observed morphological characteristics do not allow to differentiate biotypes as to their geographical location, or their resistance level to glyphosate. The genetic analysis identified low genetic diversity among the 15 tested biotypes, with a large amount of subgroups. The biotypes with low resistance formed an isolated group. The susceptible biotypes showed the lowest values of light compensation point and, possibly, they have a greater competitive ability under low-luminosity conditions. The evaluated characteristics do not enable to differentiate genotypes with different levels of glyphosate resistance.
\end{abstract}

Index terms: Euphorbia heterophylla, AFLP, competitive ability, EPSPs inhibitor herbicide, light compensation point, resistance to herbicide.

\section{Caracterização morfofisiogenética de biótipos de leiteira com baixa resistência ao glifosato}

\begin{abstract}
Resumo - O objetivo deste trabalho foi comparar biótipos de leiteira (Euphorbia heterophylla) quanto a suas características morfológicas, assim como determinar sua similaridade genética no Rio Grande do Sul e confrontar o ponto de compensação de luz de biótipos suscetíveis e com baixa resistência ao glifosato. Além da análise morfológica, o estudo incluiu a caracterização genética, por meio de AFLP, dos biótipos suscetíveis $\left(\mathrm{GR}_{50}=58,65 \mathrm{~g} \mathrm{ha}^{-1} \mathrm{e}\right.$.a. $)$ e dos biótipos com baixa resistência $\left(\mathrm{GR}_{50}=310,36 \mathrm{~g} \mathrm{ha}^{-1}\right.$ e.a. $)$ ao glifosato. A habilidade competitiva dos biótipos foi inferida por meio de seus pontos de compensação de luz. As características morfológicas observadas não permitem diferenciar os biótipos quanto à localização geográfica ou ao grau de resistência ao glifosato. A análise genética identificou baixa diversidade genética entre os 15 biótipos de leiteira testados, com formação de elevado número de subgrupos. Os biótipos com baixa resistência formaram um grupo isolado. Os biótipos suscetíveis apresentaram os menores valores de ponto de compensação de luz e, possivelmente, têm maior habilidade competitiva em condições de baixa luminosidade. As características avaliadas não permitem diferenciar os genótipos com diferentes níveis de resistência ao glifosato.
\end{abstract}

Termos para indexação: Euphorbia heterophylla, AFLP, habilidade competitiva, herbicida inibidor de EPSPs, ponto de compensação de luz, resistência a herbicidas.

\section{Introduction}

Wild poinsettia (Euphorbia heterophylla L.) is a short-lived weed of Euphorbiaceae family with annual cycle, which can have more than one generation per year. Its incidence on soybean (Glycine max L.) crops in Southern Brazil is very high, and it is one of the most important weeds for this crop. The main features of the weed are the latex production (Kissmann \& Groth, 1999) and seed dispersal by autocory. The wild 
poinsettia management in soybean crops have been improved with the Roundup Ready technology, since it generally shows low resistance to the glyphosate herbicide.

Glyphosate is a nonselective, systemic herbicide that inhibits the enzyme 5-enolpyruvylshikimate-3phosphate synthase (EPSPs), from the shikimic acid route. This enzyme catalyzes the binding reaction of shikimate-3-phosphate and phosphoenolpyruvate (PEP) compounds. Inhibition of EPSPs ceases the synthesis of aromatic amino acids (tryptophan, phenylalanine, and tyrosine) and the production of alkaloids, flavonoids, lignin, and phenolic compounds, which may represent up to $35 \%$ of plant biomass (Velini et al., 2009). The continuous use of glyphosate, often more than twice during the growing season, has been deemed the responsible for the selection of weeds with resistance to the herbicide (Ulguim et al., 2013; Vargas et al., 2013). Glyphosate is believed to have a reduced potential to select resistant weed biotypes (Powles \& $\mathrm{Yu}, 2010)$, but this concept was debunked due to the high number of resistance cases detected, $90 \%$ of which reported in the last 15 years (Heap, 2017).

Resistance is defined as the inherent and inheritable ability of a biotype within a weed population to survive and reproduce after exposure to a herbicide label rate usually lethal to the susceptible population of the species (Gazziero et al., 2014). In Brazil, there are records of wild poinsettia resistance to herbicides which are inhibitors of acetolactate synthase (ALS) and protoporphyrinogen oxidase (PPO) (Heap, 2017). However, there are also cases in which the differences in the control of certain weed biotypes are due to doses below that of the label rate for a specific biotype. These cases are considered as low- resistance levels, and do not imply that the herbicide would not control the biotype with the maximum registered rate (Gazziero et al., 2014). This low- resistance level differs from tolerance, which is defined as the proper capacity of a species to survive to applications of a certain herbicide at recommended doses, without marked changes in its growth and development (Dias et al., 2003). Several aspects of the plants are related to their resistance or tolerance to herbicides, like plant morphology.

High-epicuticular wax content, density of laticifers, and thickness of the adaxial cuticle are considered the main leaf barriers to herbicide penetration in wild poinsettia plants (Ferreira et al., 2003). These traits show the importance of morphological characteristics related to response to herbicide applications. Morphological characterization of weeds is also a tool used for establishing genetic and evolutive relationships between species and biotypes (García-Franco et al., 2014). Altop \& Mennan (2011) observed that herbicide selection pressure was responsible for morphological and genetic differentiation among Echinochloa crus-galli (L.) P. Beauv. biotypes. Therefore, the use of molecular biology techniques can confirm and complement morphological observations. The amplified fragment length polymorphism (AFLP) is a molecular marker commonly used in studies on gene flow, population structure, genetic mapping, ploidy level, genetic diversity of weeds, and characterization of resistant weed biotype (Bodo Slotta, 2008).

Weed physiological response to herbicide application is an important trait because it allows of inferences about the adaptive capacity of plants. Accordingly, light response curves make it possible to determine the light compensation point - the luminosity value which express that $\mathrm{CO}_{2}$ released by respiration and $\mathrm{CO}_{2}$ assimilated by photosynthesis are equal (Taiz et al., 2017) -, which could indicate competitive advantages of biotypes. Therefore, plants with smaller light compensation point would be more competitive due to the higher $\mathrm{CO}_{2}$ assimilation rate under conditions of reduced light availability.

The comparative characterization of susceptible wild poinsettia biotypes with the ones showing low resistance to glyphosate, reported in previous studies, is important to identify the progress of the species, and to study the competitiveness and adaptability of biotypes. In this sense, it is possible that morphological differences between wild poinsettia biotypes, besides reflecting the genetic diversity of the species, could aid the differentiation between low-resistance biotypes and susceptible ones. Moreover, these biotypes with low resistance may show lower-photosynthetic rates than the susceptible ones.

The objective of this work was as to compare wild poinsettia biotypes for their morphological characteristics, as well as to determine the genetic similarity of the weed in the state of Rio Grande do Sul, Brazil, and to confront the light compensation point of susceptible biotypes and of biotypes with lowresistance level to glyphosate. 


\section{Materials and Methods}

The study consisted of the morphology analyses, genetic characterization, and photosynthesis-level response of wild poinsettia biotypes. Seed were collected between the 2010/2011 and 2011/2012 crop seasons, in properties located in municipalities of traditional soybean production in the state of Rio Grande do Sul, Brazil. These seed were collected from plants that survived to glyphosate application, in a total of 36 biotypes. The analyses were performed in laboratory and greenhouse, from 2013 to 2015.

The morphology analyses of biotypes were divided into two stages: exsiccatae preparation for species identification and for characterization of morphology differences between collected biotypes; and analyses of main morphological characteristics of two contrasting biotypes, one of low-resistance level to glyphosate (biotype 21.1, collected from Condor, RS, Brazil - 28 $8^{\circ} 14^{\prime} 05^{\prime \prime} \mathrm{S}, 53^{\circ} 36^{\prime} 582^{\prime \prime} \mathrm{W}, \mathrm{GR}_{50}=310.36 \mathrm{~g} \mathrm{ha}^{-1}$ a.e.), and another susceptible to glyphosate (biotype 11.4, collected in Panambi, RS, Brazil - 28 $26^{\prime} 02^{\prime \prime}$, $53^{\circ} 30^{\prime} \mathrm{W}, \mathrm{GR}_{50}=58.65 \mathrm{~g} \mathrm{ha}^{-1}$ a.e.). The close proximity between the areas avoided major interference from environmental conditions on the biotype diversity.

For the preparation of exsiccatae, a representative plant was selected from each of the 36 biotypes, and deposited in the herbarium of Universidade Federal de Pelotas (Herbarium-Pel). Exsiccatae are now part of the herbarium acquis, identified with the codes from 25.945 to 25.951 , and from 26.206 to 26.234 (Table 1). Qualitative analyses were performed, in order to differentiate biotypes for the presence or absence of branching stem, hairiness in nodes and petioles, stem hairiness, blade cut, and for the occurrence of irregularities in the margin of leaf blade (Souza et al., 2013). Biotypes were then characterized according to species, following the identification key proposed by Kissmann \& Groth (1999).

In a second stage, the identification of the main morphological characters of biotype 21.1 (lowresistance level) and 11.4 (susceptible) was conducted in greenhouse, from October 2014 to January 2015. Experimental units consisted of $8.0 \mathrm{~L}$ pots filled with Typic Hapludult soil. These two biotypes were evaluated for their: plant height $(\mathrm{cm})$; width and length of blades $(\mathrm{cm})$; number, length, and width of bracts (cm); number of branches; number of double nodes; number of single nodes; number of nodes before and after dichotomous bifurcation; and total number of bifurcations. Measurements were made 76 days after transplanting, when the plants were at the full bloom stage. It was used a completely randomized design, with two treatments (biotypes 21.1 and 11.4) and four replicates. The data were analyzed concerning normality and homoscedasticity, using the ShapiroWilk and Hartley tests, respectively, with subsequent analysis of variance, at $5 \%$ probability. When statistical significance was observed, the t-test was used to compare the biotypes.

The second study consisted of molecular characterization of the collected wild poinsettia biotypes, using the AFLP method. A total of 15 biotypes was selected, whose morphological characteristics represented each collection site. The evaluated biotypes were: $2.1,3.1,5.4,6.4,7.4,9.4,11.1,11.4,14.1,15.2$, 20.2, 20.3, 21.1, and 22.1 (Table 1). DNA was extracted from $100 \mathrm{mg}$ of fully expanded fresh leaves, collected in bulk according to the protocol described by Doyle \& Doyle (1990). AFLP analysis was performed using the Analysis System I Kit (Life Technologies of Brazil Ltda., São Paulo, SP) according to manufacturer's recommendations, with EcoRI/MseI primer unmarked by radioisotope. A total of 16 primer combinations was tested in the selected biotypes. PCR reactions were performed with 5 min denaturation, at $94^{\circ} \mathrm{C}$, in the presence of formamide. Denatured samples were immediately placed on ice, before they were applied on polyacrylamide gels. PCR products were separated by electrophoresis in $6 \%$ polyacrylamide gel, at $60 \mathrm{~W}$, for 3 hours, and developed with silver nitrate (Creste et al., 2001).

The AFLP products in gel were visually examined and designated as 1 (one) for presence, and zero (0) for absence of clear bands. A binary matrix was created, and the genetic similarity was estimated using the simple matching coefficient, as recommended by Bonin et al. (2007). From the similarity matrix, a cluster analysis was performed in a sequential, agglomerative, hierarchical, and nested method (SAHN), using the unweighted pair group method with arithmetic mean (UPGMA), with the NTSYS-pc version 2.1 software. The similarity dendrogram was generated based on polymorphism between the 15 studied biotypes. The clustering consistency of dendrograms was verified with the cophenetic distance matrix; and the cophenetic

Pesq. agropec. bras., Brasília, v.52, n.11, p.987-996, nov. 2017 DOI: 10.1590/S0100-204X2017001100004 
correlation coefficient ( $\mathrm{r}$ ) between similarity matrix and obtained dendrogram was estimated.

The third study was done to evaluate the light compensation point (LCP) of the 11.4 and 21.1 biotypes. It was carried out in greenhouse, in a completely randomized design with four replicates. Each experimental unit consisted of a single plant on a $8.0-\mathrm{L}$ pot filled with Typic Hapludult soil. This experiment was carried out in a factorial design, where factor A tested the two wild poinsettia biotypes (11.4 and
21.1), and factor B tested 12 photosynthetically active photon flux density (PPFD): 0, 10, $2040,80,100,250$, $500,750,1,000,1,500$, and $2,000 \mu \mathrm{mol} \mathrm{m} \mathrm{m}^{-2} \mathrm{~s}^{-1}$. Plants were evaluated on early flowering stage, and the last expanded leaf preceding floral cyathium was used for readings.

Photosynthetic rate (A) was determined with infrared gas analyzer (IRGA), LI-6400XT model, equipped with a source of artificial lighting system and automatic injection of $\mathrm{CO}_{2}$. The correction of $\mathrm{CO}_{2}$

Table 1. Morphological characteristics analyzed in exsiccatae of wild poinsettia (Euphorbia heterophylla) biotypes, deposited on the Herbarium at Universidade Federal de Pelotas, in Brazil.

\begin{tabular}{|c|c|c|c|c|c|c|c|}
\hline \multirow[t]{2}{*}{ Biotype $^{(1)}$} & \multirow[t]{2}{*}{ County $^{(2)}$} & \multirow{2}{*}{$\begin{array}{c}\text { Herbarium } \\
\text { code }\end{array}$} & \multirow[t]{2}{*}{ Branching } & \multicolumn{2}{|c|}{ Hairiness } & \multirow{2}{*}{$\begin{array}{c}\text { Blade } \\
\text { cuttings }\end{array}$} & \multirow{2}{*}{$\begin{array}{c}\text { Blade } \\
\text { border }\end{array}$} \\
\hline & & & & Nodes and petioles & Stem & & \\
\hline 2.1 & São Borja & 26206 & Absent & Present & Absent & Absent & Irregular \\
\hline$\underline{3.1}$ & Roque Gonzales & 25945 & Present & Absent & Absent & Present & Irregular \\
\hline 4.1 & São Luiz Gonzaga & 26207 & Absent & Present & Present & Present & Irregular \\
\hline 4.2 & São Luiz Gonzaga & 26208 & Present & Present & Present & Present & Irregular \\
\hline 4.3 & São Luiz Gonzaga & 26209 & Absent & Present & Present & Present & Irregular \\
\hline 4.5 & São Luiz Gonzaga & 26210 & Absent & Present & Present & Absent & Irregular \\
\hline$\underline{4.6}$ & São Luiz Gonzaga & 26211 & Absent & Present & Present & Present & Irregular \\
\hline$\underline{5.4}$ & Capão do Cipó & 26212 & Absent & Absent & Absent & Absent & Irregular \\
\hline 6.1 & Sarandi & 26213 & Absent & Present & Absent & Absent & Irregular \\
\hline 6.2 & Sarandi & 25946 & Absent & Present & Present & Absent & Irregular \\
\hline 6.3 & Sarandi & 26214 & Absent & Present & Absent & Absent & Irregular \\
\hline$\underline{6.4}$ & Sarandi & 26215 & Absent & Present & Present & Absent & Smooth \\
\hline 6.5 & Sarandi & 26216 & Absent & Absent & Absent & Absent & Irregular \\
\hline 7.2 & Viadutos & 26217 & Absent & Absent & Absent & Absent & Smooth \\
\hline 7.3 & Viadutos & 26218 & Absent & Present & Present & Absent & Irregular \\
\hline$\underline{7.4}$ & Viadutos & 25947 & Absent & Present & Present & Absent & Smooth \\
\hline 9.1 & Lagoa Vermelha & 26219 & Absent & Present & Absent & Absent & Irregular \\
\hline 9.2 & Lagoa Vermelha & 26220 & Present & Absent & Absent & Absent & Irregular \\
\hline 9.3 & Lagoa Vermelha & 26221 & Absent & Present & Present & Absent & Irregular \\
\hline$\underline{9.4}$ & Lagoa Vermelha & 26222 & Absent & Absent & Absent & Absent & Irregular \\
\hline 9.6 & Lagoa Vermelha & 26223 & Absent & Absent & Absent & Absent & Irregular \\
\hline 9.7 & Lagoa Vermelha & 26224 & Absent & Absent & Absent & Absent & Smooth \\
\hline$\underline{11.1}$ & Panambi & 26225 & Absent & Absent & Absent & Absent & Irregular \\
\hline 11.2 & Panambi & 26226 & Absent & Present & Absent & Absent & Irregular \\
\hline$\underline{11.4}$ & Panambi & 26227 & Absent & Present & Present & Present & Irregular \\
\hline 11.5 & Panambi & 26228 & Absent & Present & Present & Present & Irregular \\
\hline$\underline{14.1}$ & Estrela Velha & 25948 & Absent & Present & Present & Absent & Irregular \\
\hline 14.2 & Estrela Velha & 25949 & Absent & Absent & Absent & Absent & Irregular \\
\hline 14.3 & Estrela Velha & 25950 & Present & Present & Present & Absent & Irregular \\
\hline 14.4 & Estrela Velha & 26229 & Present & Absent & Absent & Absent & Irregular \\
\hline$\underline{15.2}$ & Nova Palma & 26230 & Absent & Absent & Absent & Absent & Irregular \\
\hline 20.1 & Pontão & 26231 & Present & Present & Absent & Absent & Irregular \\
\hline$\underline{20.2}$ & Pontão & 26232 & Absent & Present & Absent & Present & Irregular \\
\hline$\underline{20.3}$ & Pontão & 26233 & Absent & Present & Present & Absent & Irregular \\
\hline$\underline{21.1}$ & Condor & 25951 & Present & Present & Absent & Absent & Irregular \\
\hline 22.1 & Capão do Leão & 26234 & Absent & Present & Present & Absent & Irregular \\
\hline
\end{tabular}

${ }^{(1)}$ Underlined biotypes were the selected ones for genetic analysis. ${ }^{(2)}$ State of Rio Grande do Sul, Brazil. 
inside the chamber was established for $400 \mu \mathrm{mol} \mathrm{mol}^{-1}$, leaf temperature at $22^{\circ} \mathrm{C}$, and air flow rate of 500 $\mu \mathrm{mol} \mathrm{s} \mathrm{s}^{-1}$. For the LCP and quantum efficiency $(\mathrm{QE})$ determinations, the response of $A$ due to increases from 0 to $100 \mu \mathrm{mol} \mathrm{m} \mathrm{m}^{-2} \mathrm{~s}^{-1}$ in PPFD was adjusted to a linear regression. The regression enables the determination of LCP ( $\left.\mu \mathrm{mol} \mathrm{m} \mathrm{m}^{-2} \mathrm{~s}^{-1}\right)$, by equaling net photosynthesis (A) to zero; and the angular coefficient $b$ of the linear equation represents the apparent $\mathrm{QE}\left(\mu \mathrm{mol} \mathrm{CO}{ }_{2} \mu \mathrm{mol}^{-1}\right.$ photons).

The obtained data were subjected to Shapiro-Wilk and Hartley tests for normality and homoscedasticity evaluations, respectively, with subsequent analysis of variance, at $5 \%$ probability. Photosynthetic rates related to each PPFD were adjusted to the hyperbole model with two parameters, as follows: $\mathrm{y}=\mathrm{y}_{0}+(\mathrm{ax} / \mathrm{b}+\mathrm{x})$, in which $\mathrm{y}$ is the photosynthetic response; $\mathrm{y}_{0}$ indicates the $\mathrm{y}$ value when PPFD is zero; $\mathrm{a}$ and $\mathrm{b}$ are equation parameters; and $\mathrm{x}$ is the PPFD.

\section{Results and Discussion}

Exsiccatae analysis allowed to infer that the biotypes differed as to their morphological characters (Table 1). Prevalence was observed for the following traits: branching absence, $81 \%$; presence of hairiness in nodes and petioles, 67\%; absence of hairiness in stem, 55\%; absence of leaf blade cutting, $78 \%$; and regular occurrence of blades, $89 \%$. Hairiness in stem was observed in $40 \%$ of cases, and contrasted with the presence of the trait (hairiness) in nodes and petioles. These results show that, even when collected in nearby areas, wild poinsettia biotypes can show a great morphological diversity.

The species is normally characterized as an annual herbaceous plant, with typically glabrous and erect simpodial stem and dichotomous branching in the upper portion (Kissmann \& Groth, 1999). Leaf blades may differ markedly, with lanceolate, asymmetric, oblong, oval, and elliptical formats, among others, in addition to smooth, lobed, toothed, and serrated blades (Souza et al., 2013). Thus, this species has a high heterophilia, which is the reason for its specific epithet (heterophylla). This trait is possibly related to the fact that wild poinsettia belongs to a botanical family with recent evolutionary origin. In the present study, all collected biotypes were considered to belong to the Euphorbia heterophylla species, but it possibly included different botanical varieties (Kissmann \& Groth, 1999).

The morphological characteristics analyzed in exsiccatae did not allow to distinguish biotypes, neither grouping them according to the analyzed traits (Table 1), showing expressive differences between biotypes and regions, even among biotypes from the same county. However, there were some predominant traits, mainly: absence of branching, presence of hairiness in nodes and petioles, absence of hairiness on stems, absence of blade cutting, and irregular blades.

The more detailed morphological analysis was performed in biotypes 21.1 and 11.4 (Tables 2 and 3). Once again, the biotypes did not show expressive differences between them, but there were significant ones in traits related to plant stems: number of single and double nodes, and number of nodes located before the dichotomous branching (Table 3). It should be stressed that these two biotypes were used due to their nearby locations, which aimed at reducing the environmental effects on the traits.

The number of single nodes and of nodes before bifurcation was higher in the low-resistance level biotype 21.1 (Table 3). These traits may favor a greater leaf density in the basal portion of plants, when combined with the lower number of nodes after the dichotomous branching, but they apparently have no

Table 2. Morphological traits of wild poinsettia (Euphorbia heterophylla) biotypes with low-resistance level (21.1) and susceptible (11.4) to glyphosate.

\begin{tabular}{lcccccc}
\hline Biotype & Plant height & Blade width & Blade length & Bract width & $\begin{array}{c}\text { Bract length } \\
\text { Number of } \\
\text { bracts }\end{array}$ \\
\hline 11.4 & $-131.5^{\text {ns }}$ & $5.1^{\text {ns }}$ & $9.6^{\text {ns }}$ & $7.0^{\text {ns }}$ & $1.1^{\text {ns }}$ & $3.3^{\text {ns }}$ \\
21.1 & 116.9 & 4.4 & 12.6 & 7.0 & 0.9 & 3.7 \\
\hline CV (\%) & 8.47 & 10.45 & 26.88 & 20.59 & 18.75 & 11.05 \\
\hline
\end{tabular}

${ }^{\mathrm{n}}$ Nonsignificant. 
impact on resistance to glyphosate. However, biotype 11.4 had more double nodes, which suggests a greater leaf area, since most nodes showed two leaves.

Moreover, biotype 21.1 had, in general, leaves with the linear type, that is, wider leaves in the center, with narrower parallel borders. This was confirmed by the observed ratio between length and blade width, which was close to 3.0 in this biotype (Table 3 ). Thus, this trait, combined to the lower-leaf area of this biotype, compared to the biotype 11.4, would provide lower-leaf contact with applied herbicides. However, there was no evidence that this low-resistance level on biotype 21.1 occur due these morphological characteristics. In a similar study, García-Franco et al. (2014) did not identify morphological traits related to resistance or susceptibility to inhibiting herbicides of Acetyl-CoA carboxylase enzyme (ACCase) in Phalaris minor Retz biotypes.

Molecular methods are complementary to morphological analyses, and they are highly precise in providing the molecular basis of a given trait (D'Imperio et al., 2011). The AFLP analysis showed that out of the 16 primer combinations tested, a total of
12 ones showed consistent amplifications, generating 214 banding profiles (Table 4), 166 of which were polymorphic (approximately 78\% polymorphism). Considering only the bands that developed with high intensity in gel (Figure 1), the total number of polymorphic bands generated from each primer combination ranged from 5 to 38 , with an average of 18 bands (Table 4). The primer combinations with the largest number of polymorphic bands were E-AAG/ M-CTA (28) and E-ACG/M-CAA (26).

The amplified fragments had between 125 to $2,080 \mathrm{bp}$, with an average close to $370 \mathrm{bp}$, for smaller fragments, and to $1,500 \mathrm{bp}$, for larger ones (Table 4; Figure 1). Chandi et al. (2013) showed a total of 997 AFLP bands, 945 of which were polymorphic (95\% polymorphism), and ranged from 63 to $700 \mathrm{bp}$, in Amaranthus palmeri S. Wats populations resistant and susceptible to glyphosate.

Genetic diversity within and between weed populations may influence management practices, in order to avoid the selection of resistant biotypes (Sterling et al., 2004). Populations of resistant species with self-fecundation often exhibit low genetic

Table 3. Morphological characteristics related to stem of wild poinsettia (Euphorbia heterophylla) biotypes with low resistance (21.1) and susceptible (11.4) to glyphosate.

\begin{tabular}{lccccccc}
\hline Biotype & Branches & $\begin{array}{c}\text { Double } \\
\text { nodes }\end{array}$ & $\begin{array}{c}\text { Single } \\
\text { nodes }\end{array}$ & $\begin{array}{c}\text { Nodes before } \\
\text { bifurcation }\end{array}$ & $\begin{array}{c}\text { Nodes after } \\
\text { bifurcation }\end{array}$ & $\begin{array}{c}\text { Number of } \\
\text { bifurcations }\end{array}$ \\
\hline 11.4 & $3.8^{\text {ns }}$ & $41.0^{*}$ & $33.0^{*}$ & $9.0^{*}$ & $12.0^{\text {ns }}$ & $17.0^{\text {ns }}$ \\
21.1 & 6.3 & 25.0 & 52.0 & 14.0 & 20.0 & 19.0 & 18.75 \\
\hline CV (\%) & 8.47 & 10.45 & 26.88 & 20.59 & 1.05 & 18.75 \\
\hline
\end{tabular}

${ }^{n s}$ Nonsignificant. *Significant by the t-test, at $5 \%$ probability.

Table 4. Primer combinations, number of high-intensity fragments in gel and of observed polymorphisms, and fragment size (bp) for 15 wild poinsettia (Euphorbia heterophylla) biotypes.

\begin{tabular}{lcccc}
\hline $\begin{array}{l}\text { Primer } \\
\text { combination }\end{array}$ & $\begin{array}{c}\text { Number of } \\
\text { fragments }\end{array}$ & $\begin{array}{c}\text { Number of } \\
\text { polymorphisms }\end{array}$ & \multicolumn{2}{c}{ Fragment size (bp) } \\
\hline E-AAG/M-CTA & 38 & 28 & 125 & Smaller \\
E-AAG-M-CTG & 32 & 20 & 250 & 2080 \\
E-ACT/M-CTA & 7 & 7 & 600 & 2080 \\
E-ACA/M-CTA & 13 & 13 & 500 & 1250 \\
E-ACT/M-CAT & 22 & 15 & 500 & 2080 \\
E-AGC/M-CTA & 8 & 8 & 350 & 2080 \\
E-ACG/M-CAA & 35 & 26 & 200 & 200 \\
E-ACG/M-CTA & 15 & 10 & 600 & 2080 \\
E-ACG/M-CAG & 12 & 10 & 700 & 2080 \\
E-ACC/M-CTG & 13 & 11 & 150 & 200 \\
E-ACC/M-CTT & 5 & 5 & 200 & 300 \\
E-ACG/M-CTG & 14 & 13 & 250 & - \\
Total & 214 & 166 & - & 800 \\
\hline
\end{tabular}


diversity, in comparison to susceptible populations (Stankiewicz et al., 2001).

The genetic diversity among the tested 15 biotypes was considered low, with a simple matching (SMG) genetic similarity coefficient of approximately $81 \%$, and 6 subgroups (Figure 2): G1, biotype 4.6; G2, biotype 3.1; G3, biotype 2.1; G4, biotype 21.1; G5, biotype 6.4; and G6, other biotypes. The cophenetic correlation was high $(\mathrm{r}=0.97)$, indicating that the dendrogram properly represented the estimated distances, based on the similarity matrix obtained from polymorphic AFLP bands. Genetic diversity among susceptible and resistant populations of Amaranthus palmeri to glyphosate, from different sites in the United States, was considered low, with a maximum of $49 \%$ similarity between them (Chandi et al., 2013). Moreover, genetic diversity estimated with Nei's gene diversity technique in populations of Chenopodium album L., resistant and susceptible to the II photosystem inhibitors herbicide, was low (0.073) for the whole dataset (Aper et al., 2010). Therefore, the genetic similarity observed in the present work can be considered high, in comparison to these aforementioned ones.

Winkler et al. (2003) studied 40 wild poinsettia populations resistant to ALS inhibitors, in Rio Grande do Sul, and reported genetic similarity of $40 \%$, which indicates no gene flow between these populations and limited dispersion. Frigo et al. (2009) genetically characterized 12 wild poinsettia populations, in the states of Paraná and Mato Grosso, and observed that the populations were genetically structured, with a high index of homozygosity attributed to the herbicide selection pressure.

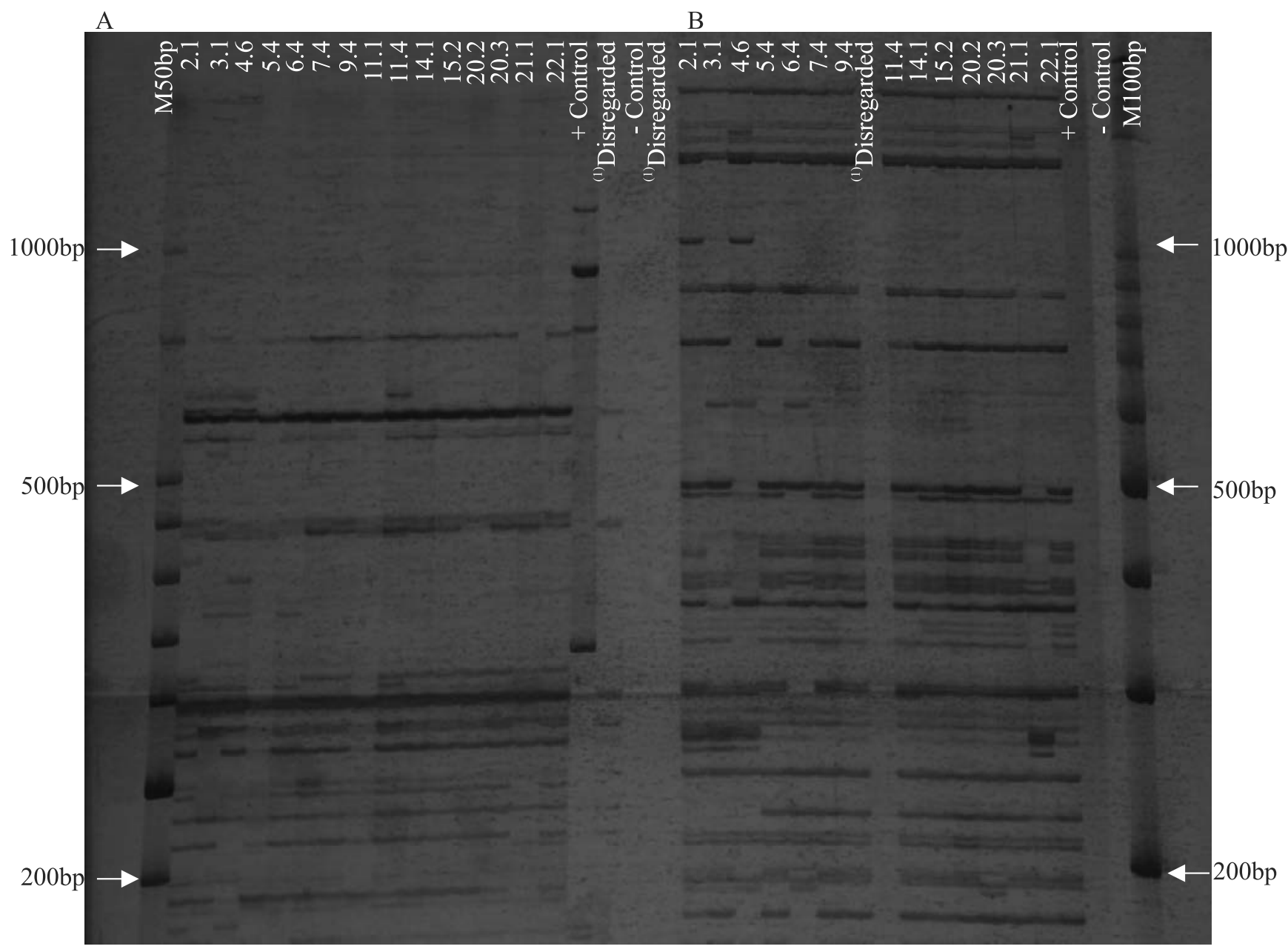

Figure 1. Example of polyacrylamide gel (6\%) containing: A, two E-AGC/M-CTA; and B, E-ACG/M-CAA primer combinations for 15 wild poinsettia (Euphorbia heterophylla) biotypes tested with the AFLP technique. + Control: Arabdopsis DNA. - Control, sample without DNA. ${ }^{(1)}$ Disregarded sample. 
The six subgroups in the hierarchical analysis, in the present study, are similar to others reported in the literature for wild poinsettia biotypes (Winkler et al., 2003). The formed subgroups were not correlated with the evaluated morphological characteristics, although the great majority of biotypes belonged to G6, and showed similar traits regarding the presence of branching, cutting border, and blade border (Table 1).

G1 and G3 subgroups were the least similar ones, with 59\% genetic similarity. However, there were some biotypes with lower similarity (54\%), as observed between biotype 4.6, from São Luiz Gonzaga, and biotype 22.1, from the municipality of Capão do Leão. Furthermore, it was observed that, on average, the genetic similarity between subgroup 1 and other subgroups was $58 \%$, and the biotype 4.6 was the most genetically distinct. The subgroup 1 contain biotypes that were collected in geographically distant regions from the other subgroups. To Euphorbia esula L., a lower genetic diversity was observed for populations from nearby areas (Rowe et al., 1997), which agrees with our results. However, studies on wild poinsettia reported that genetic diversity was not dependent on the geographic distance (Frigo et al., 2009), which indicates a need for more works to confirm these discrepancies in the results.

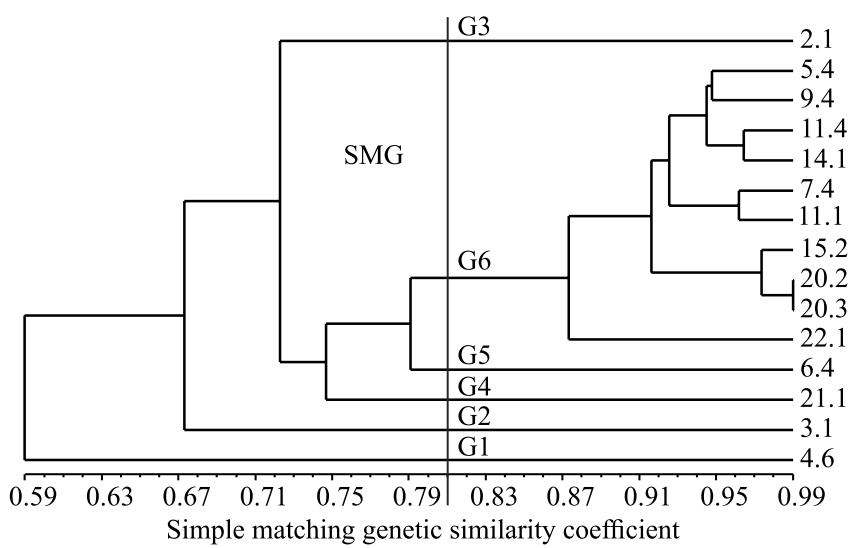

Figure 2. Dendogram of genetic similarity among 15 wild poinsettia (Euphorbia heterophylla) biotypes obtained by unweighted pair group method with arithmetic mean (UPGMA), and calculated by the simple matching similarity coefficient. SMG, average genetic similarity; simple macthing similarity coefficient, 0.81 ; and cophenetic correlation, 0.97 .
It was not possible to establish a relationship between response to glyphosate herbicide and genetic similarity, although the low-resistance biotype 21.1 formed alone a subgroup (Figure 2). Biotype 20.2, which is also a low-resistance one, was grouped in subgroup 6 together with the susceptible biotypes 11.4 and 22.1. Thus, it was not possible to consider the low-resistance level to glyphosate a relevant trait for differentiating wild poinsettia biotypes, neither at the genetic nor at the morphological level.

Chandi et al. (2013) observed the formation of subgroups according to Amaranthus palmeri geographic distribution, regardless of the population response to glyphosate. The low genetic variability in some weed populations resistant to herbicides results from the application of products with specific action site (Aper et al., 2010), such as glyphosate. In these cases, the frequency of resistant genotypes increases after repeated applications, and the weed population may be subjected to the genetic bottleneck effect (Aper et al., 2010). Thus, selection for glyphosate may favor a lower genetic diversity of wild poinsettia.

Wild poinsettia biotypes showed significant differences in the photosynthetic rates of biotypes 21.1 and 11.4 (Figure 3). With the maximum PPFD of $2,000 \mu \mathrm{mol} \mathrm{m} \mathrm{m}^{-2} \mathrm{~s}^{-1}$ - the photosynthetic rates were 18.62 and $15.45 \mu \mathrm{mol} \mathrm{CO} \mathrm{CO}^{-2} \mathrm{~s}^{-1}$ for the biotypes 11.4 and 21.1, respectively. The point of light saturation for these biotypes was close to $1,000 \mu \mathrm{mol} \mathrm{m} \mathrm{m}^{-2} \mathrm{~s}^{-1}$ with 88 and $80 \%$ of maximum photosynthesis at this point, for the biotypes 11.4 and 21.1, respectively.

The quantum efficiencies were 0.0542 and $0.0571 \mu \mathrm{mol} \mathrm{CO}_{2}$ per $\mu \mathrm{mol}$ photon, for biotypes 11.4 and 21.1 (Figure 3). The QE values refer to the ratio of $\mathrm{CO}_{2}$ assimilation and the number of absorbed photons, and ranges from 0 to 1 . Taking the inverse of the angular coefficient of the linear equations $(\mathrm{QE}$ values), approximately $18 \mu \mathrm{mol}$ of photons were found as necessary for fixing $1.0 \mu \mathrm{mol} \mathrm{CO}_{2}$. However, the light compensation point ranged from $20 \mu \mathrm{mol} \mathrm{m}^{-2} \mathrm{~s}^{-1}$ of PPFD, for biotype 11.4, and $37 \mu \mathrm{mol} \mathrm{m} \mathrm{m}^{-2} \mathrm{~s}^{-1}$ for biotype 21.1. The lower light compensation point imply a greater competitive advantage of the susceptible biotype 11.4 under conditions of lower luminosity, such as those commonly observed under crop canopy (Dias-Filho, 2002). However, more studies are needed to confirm this possibility. 

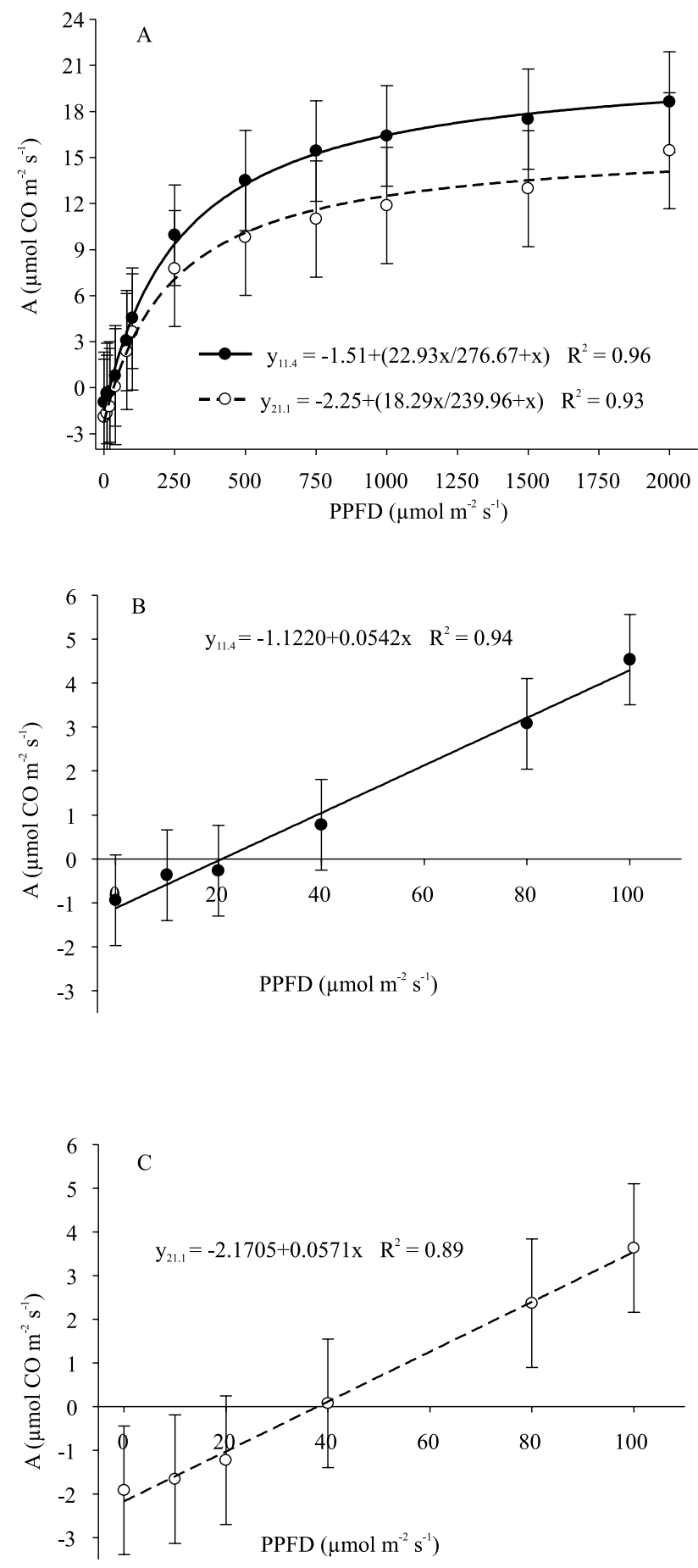

Figure 3. Effect of photosynthetically active photon flux density (PPFD) on photosynthetic rate of wild poinsettia (Euphorbia heterophylla) biotypes (A); linear portions: from 0 to $100 \mu \mathrm{mol} \mathrm{m} \mathrm{m}^{-2} \mathrm{~s}^{-1}$ of PPFD - observed in susceptible (11.4) (B), and in low-resistance level (21.1) biotypes (C). Bars represent the confidence interval for each biotype between different PPFD, at 5\% probability. Coefficient of variation $22.0 \%$.

\section{Conclusions}

1. The morphology of wild poinsettia (Euphorbia heterophylla) biotypes does not differentiate them; however, comparative analysis of the susceptible (11.4) and low-resistance level (21.1) biotypes shows a higher simple nodes and nodes before dichotomous bifurcation in 21.1 biotype, and double nodes in the biotype 11.4 .

2. The AFLP analysis shows a great similarity between the wild poinsettia biotypes.

3. The light compensation point is lower in the susceptible wild poinsettia biotype (11.4).

\section{Acknowledgments}

To Fundação de Apoio à Pesquisa do Estado do Rio Grande do Sul (Fapergs) and to Conselho Nacional de Desenvolvimento Científico e Tecnológico (CNPq), for financial support (Edital 22/2010).

\section{References}

ALTOP, E.K.; MENNAN, H. Genetic and morphologic diversity of Echinochloa crus-galli populations from different origins Phytoparasitica, v.39, p.93-102, 2011. DOI: 10.1007/s12600-0100135-3.

APER, J.; DE RIEK, J.; MECHANT, E.; DE CAUWER, B.; BULCKE, R.; REHEUL, D. The origin of herbicide-resistant Chenopodium album: analysis of genetic variation and population structure. Weed Research, v.50, p.235-244, 2010. DOI: 10.1111/j.1365-3180.2010.00777.x.

BODO SLOTTA, T.A. What we know about weeds: insights form genetic markers. Weed Science, v.56, p.322-326, 2008. DOI: 10.1614/WS-07-064.1.

BONIN, A.; EHRICH, D.; MANEL, S. Statistical analysis of amplified fragment length polymorphism data: a toolbox for molecular ecologists and evolutionists. Molecular Ecology, v.16, p.3737-3758, 2007. DOI: 10.1111/j.1365-294X.2007.03435.x.

CHANDI, A; MILLA-LEWIS, S.R.; JORDAN, D.L.; YORK, A.C.; BURTON, J.D.; ZULETA, M.C.; WHITAKER, J.R.; CULPEPPER, A.S. Use of AFLP markers to assess genetic diversity in Palmer amaranth (Amaranthus palmeri) populations from North Carolina and Georgia. Weed Science, v.61, p.136-145, 2013. DOI: 10.1614/WS-D-12-00053.1.

CRESTE, S.; TULMANN NETO, A.; FIGUEIRA, A. Detection of single sequence repeat polymorphisms in denaturing polyacrylamide sequencing gels by silver staining. Plant Molecular Biology Reporter, v.19, p.299-306, 2001. DOI: 10.1007/BF02772828.

D'IMPERIO, M.; VISCOSI, V.; SCARANO, M.-T.; D'ANDREA, $\mathrm{M}$. Integration between molecular and morphological markers 
for the exploitation of olive germoplasm (Olea europaea). Scientia Horticulturae, v.130, p.229-240, 2011. DOI: 10.1016/j. scienta.2011.06.050.

DIAS, N.M.P.; REGITANO, J.B.; CHRISTOFFOLETI, P.J.; TORNISIELO, V.L. Absorção e translocação do herbicida diuron por espécies suscetível e tolerante de capim-colchão (Digitaria spp.). Planta Daninha, v.21, p.293-300, 2003. DOI: 10.1590/ S0100-83582003000200015.

DIAS-FILHO, M.B. Photosynthetic light response of the $\mathrm{C}_{4}$ grasses Brachiaria brizantha and B. humidicola under shade. Scientia Agricola, v.59, p.65-68, 2002. DOI: 10.1590/S010390162002000100009.

DOYLE, J.J.; DOYLE, J.L. Isolation of plant DNA from fresh tissue. Focus, v.12, p.13-15, 1990.

FERREIRA, E.A.; PROCÓPIO, S.O.; SILVA, E.A.M.; SILVA, A.A.; RUFINO, R.J.N. Estudos anatômicos de folhas de espécies de plantas daninhas de grande ocorrência no Brasil. IV - Amaranthus deflexus, Amaranthus spinosus, Alternanthera tenella e Euphorbia heterophylla. Planta Daninha, v.21, p.263271, 2003. DOI: 10.1590/S0100-83582003000200012.

FRIGO, M.J.; MANGOLIN, C.A.; OLIVEIRA JR., R.S.; MACHADO, M. de F.P.S. Esterase polymorphism for analysis of genetic diversity and structure of wild poinsettia (Euphorbia heterophylla) populations. Weed Science, v.57, p.54-60, 2009. DOI: 10.1614/WS-08-096.1.

GARCÍA-FRANCO, J.L.; USCANGA-MORTERA, E.; KOHASHI-SHIBATA, J.; GARCÍA-ESTEVA, A.; YÁÑEZJIMÉNEZ, P.; ORTEGA-ESCOBAR, H.M. Caracterización morfológica de biotipos de Phalaris minor resistentes y susceptible a herbicidas inhibidores de la ACCASA. Botanical Sciences, v.92, p.169-176, 2014. DOI: 10.17129/botsci.44.

GAZZIERO, D.L.P.; CHRISTOFFOLETI, P.J.; VARGAS, L.; KRUSE, N.D.; GALLI, A.J.B.; TREZZI, M.M. Critérios para relatos oficiais estatísticos de biótipos de plantas daninhas resistentes a herbicidas. In: AGOSTINETTO, D.; VARGAS, L. (Ed.) Resistência de plantas daninhas a herbicidas no Brasil. Pelotas: Ed. da UFPel, 2014. p.81-91.

HEAP, I. International survey of herbicide resistant weeds. Available at: <www.weedscience.org $>$. Accessed on: Apr. 72017.

KISSMANN, K.G.; GROTH, D. Plantas infestantes e nocivas. São Paulo: Basf, 1999. t.2, 978p.
POWLES, S.B.; YU, Q. Evolution in action: plants resistant to herbicides. Annual Review of Plant Biology, v.61, p.317-347, 2010. DOI: 10.1146/annurev-arplant-042809-112119.

ROWE, M.L.; LEE, D.J.; NISSEN, S.J.; BOWDITCH, B.M.; MASTERS, R.A. Genetic variation in North American leafy spurge (Euphorbia esula) determined by DNA markers. Weed Science, v.45, p.446-454, 1997.

SOUZA, V.C.; FLORES, T.B.; LORENZI, H. Introdução à Botânica. São Paulo: Instituto Plantarum de Estudos da Flora, 2013. 224p.

STANKIEWICZ, M.; GADAMSKI, G.; GAWRONSKI, S.W. Genetic variation and phylogenetic relationships of triazineresistant and triazine-susceptible biotypes of Solanum nigrum analysis using RAPD markers. Weed Research, v.41, p.287-300, 2001. DOI: $10.1046 /$ j.1365-3180.2001.00238.x.

STERLING, T.M.; THOMPSON, D.C.; ABBOTT, L.B. Implications of invasive plant variation for weed management. Weed Technology, v.18, p.1319-1324, 2004. DOI: 10.1614/0890-037X(2004)018[1319:IOIPVF]2.0.CO;2.

TAIZ, L.; ZEIGER, E.; MØLLER, I.M.; MURPHY, A. Fisiologia e desenvolvimento vegetal. 6.ed. Porto Alegre: Artmed, 2017.

ULGUIM, A. da R.; VARGAS, L.; AGOSTINETTO, D.; DAL MAGRO, T.; WESTENDORFF, N. da R.; HOLZ, M.T. Manejo de capim pé-de-galinha em lavouras de soja transgênica resistente ao glifosato. Pesquisa Agropecuária Brasileira, v.48, p.17-24, 2013. DOI: 10.1590/S0100-204X2013000100003.

VARGAS, L.; NOHATTO, M.A.; AGOSTINETTO, D.; BIANCHI, M.A.; PAULA, J.M.; POLIDORO, E.; TOLEDO, R.E. Práticas de manejo e a resistência de Euphorbia heterophylla aos inibidores da ALS e tolerância ao glyphosate no Rio Grande do Sul. Planta Daninha, v.31, p.427-432, 2013. DOI: 10.1590/S010083582013000200021.

VELINI, E.D.; DUKE, S.O.; TRINDADE, M.L.B.; MESCHEDE, D.K.; CARBONARI, C.A. Modo de ação do glyphosate. In: VELINI, E.D.; MESCHEDE, D.K.; CARBONARI, C.A.; TRINDADE, M.L.B. (Ed.) Glyphosate. Botucatu: FEPAF, 2009. p.113-134.

WINKLER, L.M.; VIDAL, R.A.; BARBOSA NETO, J.F. Caracterização genética de Euphorbia heterophylla resistente a herbicidas inibidores da acetolactato sintase. Pesquisa Agropecuária Brasileira, v.38, p.1067-1072, 2003. DOI: 10.1590/ S0100-204X2003000900007.

Received on December 12, 2016 and accepted on April 27, 2017 